\title{
Tracheobroncial colonization in coronary care unit intubated patients
}

\author{
A Spyrou ${ }^{1,2^{*}}$, J Triklis ${ }^{3}$, Z Aggelpopoulou ${ }^{2}$, S Tsiodras ${ }^{4}$, G Saroglou ${ }^{2}$ \\ From International Conference on Prevention \& Infection Control (ICPIC 2011) \\ Geneva, Switzerland. 29 June - 2 July 2011
}

\section{Introduction / objectives}

Tracheobronchial tree colonization is considered an important risk factor for the development of ventilatorassociated pneumonia (VAP). The aim of the present study was to examine microbiologically the respiratory tract flora of mechanically ventilated patients hospitalized in the Coronary Care Unit (CCU) of our institution for the detection of colonization with important bacterial pathogens.

\section{Methods}

Cultures of bronchial excretions were taken the first $24 \mathrm{~h}$ of intubation and before extubation, in a total of 39 CCU patients (mean age 68.7 $\pm 11.9 y r s, 79,6 \%$ men). Risk factors for colonization, including APACHE II score, Clinical Pulmonary Infection Score (CPIS), placement of an invasive device as well as the duration of mechanical ventilation (MV), were recorded.

\section{Results}

$46 \%$ of the participants with normal flora in the first 24 hours of intubation, were colonized with potential pathogens by the day of extubation. The most frequently isolated colonizers were Acinetobacter spp, MRSA, MSSA, Escherichia coli, Candida albicans, Enterobacter spp and Serratia marcescens. Patients who were colonized by potential pathogens had higher CPIS compared to those who were not $(\mathrm{p}<, 001)$. Colonization with a potential pathogen was associated with placement of a nasogastric catheter $(\mathrm{p}=, 048)$ or a central vein catheter $(\mathrm{p}=, 004)$, with the duration of $\mathrm{MV}(\mathrm{p}=, 010)$ and placement of an Intra-Aortic Balloon Pump $(\mathrm{p}=, 009)$ for a prolonged period.

${ }^{1}$ Coronary Care Unit, Onassis Cardiac Surgery Center, Athens, Greece Full list of author information is available at the end of the article

\section{Conclusion}

High rates of bacterial colonization were identified in this cohort of CCU patients. The risk factors identified will assist in the establishment of a better infection control protocol in the future.

\section{Disclosure of interest}

None declared.

\section{Author details}

${ }^{1}$ Coronary Care Unit, Onassis Cardiac Surgery Center, Athens, Greece.

${ }^{2}$ Faculty of Nursing, University of Athens, Athens, Greece. ${ }^{3}$ Emergency Department, Onassis Cardiac Surgery Center, Athens, Greece. ${ }^{4} 4$ th

Department of Medicine, University of Athens, Athens, Greece.

Published: 29 June 2011

\section{doi:10.1186/1753-6561-5-S6-P67}

Cite this article as: Spyrou et al:: Tracheobroncial colonization in coronary care unit intubated patients. BMC Proceedings 2011 5(Suppl 6): P67.
Submit your next manuscript to BioMed Central and take full advantage of:

- Convenient online submission

- Thorough peer review

- No space constraints or color figure charges

- Immediate publication on acceptance

- Inclusion in PubMed, CAS, Scopus and Google Scholar

- Research which is freely available for redistribution
C Biomed Central
C Biomed Central

(0) 2011 Spyrou et al; licensee BioMed Central Ltd. This is an open access article distributed under the terms of the Creative Commons Attribution License (http://creativecommons.org/licenses/by/2.0), which permits unrestricted use, distribution, and reproduction in any medium, provided the original work is properly cited. 